\title{
CIRCULAR TANK DESIGN AND FUNCTION IN RECIRCULATING AQUACULTURE SYSTEM (RAS)
}

\author{
Oleh \\ Supono ${ }^{1)}$
}

\section{ABSTRAK}

\section{DISAIN DAN FUNGSI TANGKI BULAT DALAM SISTEM BUDIDAYA} TERESIRKULASI. Kegiatan budidaya telah berkembang pesat dalam hal teknologi dan teknik budidaya dalam rangka meningkatkan hasil produksi. Salah satu teknologi penting adalah desain tanki yang digunakan dalam kegiatan budidaya terutama pada sistem budidaya resirkulasi. Tanki bulat memiliki beberapa keuntungan dan spesifikasi yang lebih luas dibandingkan dengan jenis tanki yang lain. Dari segi desain dan fungsinya, tanki bulat dapat di gunakan untuk budidaya berbagai jenis ikan. Tulisan ini bertujuan untuk menjelaskan desain dan fungsi dari tanki bulat terutama bagaimana memilih ukuran tanki yang sesuai dengan kebutuhan, bagaimana menginstalasi saluran air masuk dan keluar, bagaimana proses mekanisme self cleaning (mekanisme pembersihan tank secara otomatis) dan kekurangannya dalam kegiatan budidaya.

\section{INTRODUCTION}

Aquaculture has grown at an impressive rate to address the increasing global demand of fisheries products. The fact that the world's capture fisheries products showed a steady production in the last few decades (FAO, 2016), aquaculture has developed a wide range of techniques and technologies to improve fisheries production supply. Referring to how water contacts with environment, aquaculture practices are generally distinguished into open aquaculture system and closed aquaculture system (Stickney, 1994). Recirculating aquaculture system (RAS) is commonly applied in indoor (closed) system by which a negligible amount of water is discharged into another body water (Adamu et al., 2014). RAS is advantageous in terms of water utilization which allows system to reuse a majority of water instead of emitting it directly to the environment, prevent biological pollution resulted from aquaculture practices and increase disease management control (Adamu et al., 2014). The good design of RAS is determined by solid removal system, piping size selection and layout, filtration process, oxygenation, disinfection process, culture tank size and design (Morey, 2009; Timmons et al., 1998; Timmons et al., 2002).

\footnotetext{
${ }^{1)}$ LKBL LIPI Bitung, Pusat Penelitian Oseanogafi, Jl. Pardurusa, Kec. Aertembaga, Bitung, Sulawesi Utara
} 
Tanks used in intensive fish cultures are varied in shapes, sizes and flow patterns. Several important aspects are needed to be carefully considered, i.e. including space utilization, production cost, the ability to maintain water quality, the effectiveness in removing manure and managing fish in the system (Timmons et al., 1998; Timmons et al.,2002). Recently, circular tanks are widely used in a large scale of fish aquaculture production. The geometrical characteristics of a circular tank are beneficial compared to other types of culture tanks. Circular tanks provide a rotating flow (Duarte et al., 2011), which require simple and relatively low cost maintenance, improve the uniformity of culture environment, allow a wide range of rotational water velocities, allow rapid concentration and removal of solid waste and allow visual direct observation on feed waste to control feeding delivery (Timmons et al., 1998). This article reviews the application of circular tank in RAS including its design and function, size selection, inlet and outlet integration and the problems in fish aquaculture practice using RAS.

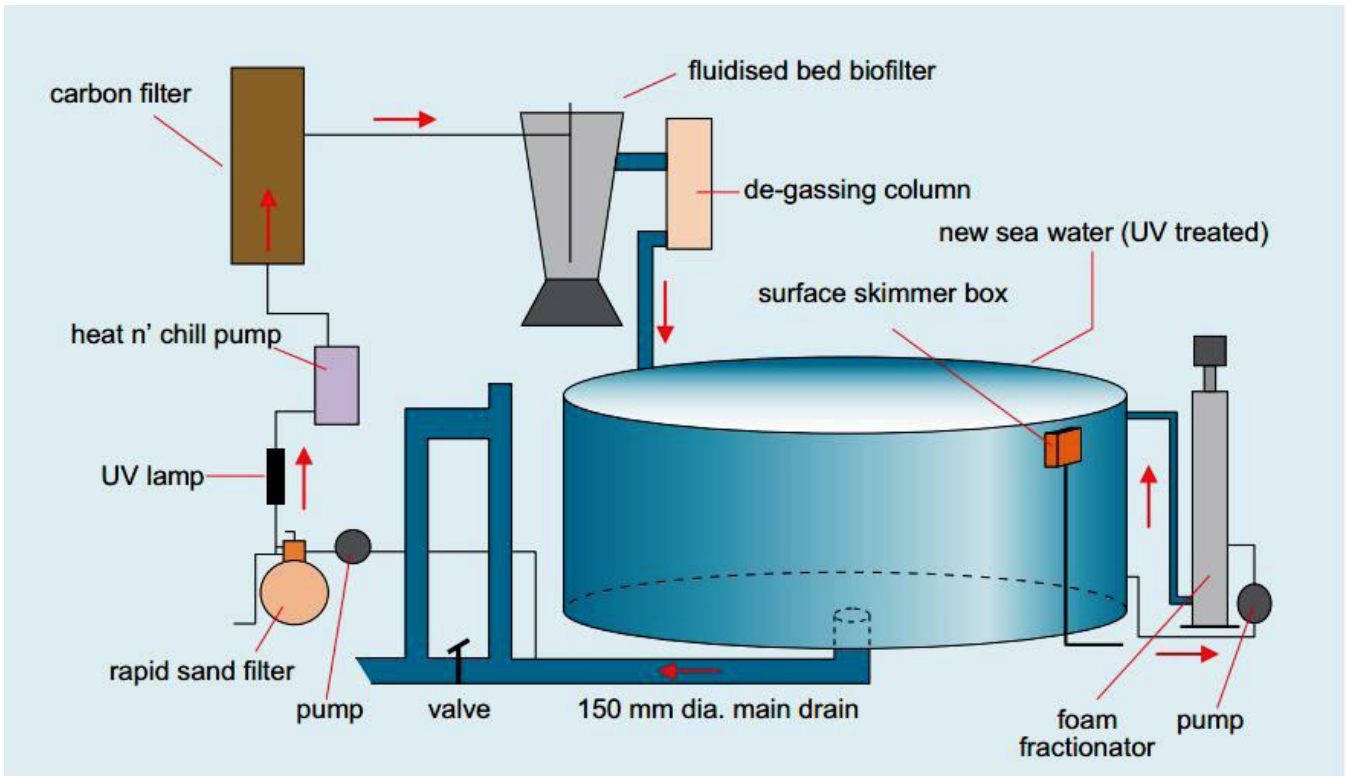

Figure 1. The design of RAS in barramundi culture using a circular tank in Northern Territory Australia (Schipp et al., 2007)

\section{Design and function}

The application of circular tank for intensive fish culture is varied depending on the availability of floor space, cultured fish behavior, stocking density and production cost (Ross \& Watten, 1998).
In relation to the limited floor space, large size and small number of tanks are usually used (Timmons \& Ebeling, 2017). Meanwhile, the fish behavior including swimming area preference determines the depth ratio of the tank. A 
case in point is Turbot (Psetta maxima) which occupies bottom floor of the tank requires lower water depth of tank, while Tilapia (Oreochromis niloticus) which occupies water column need higher water depth of tank (Belal, 2015).

\section{Size Selection}

The size selection and the required number of tanks in RAS can determine the success of fish production. The recommended ratio of tank diameter to depth, varied from 3:1, 5:1 and 10:1 depending on water head, stocking density, cost of floor space and feeding level (Cripps \& Poxton, 1992; Timmons et al., 2002). The application of a large size tank with few numbers in a system faces a challenge related to high risk of mortality due to tank failure. The feeding and organic nutrient load in a large tank may cause rapid water quality depletion and cause mass mortality of fish. Another drawback of utilizing large tanks is that if the RAS is failed to operate properly due to technical issues, i.e. electricity outage, it will cause the loss of the entire cultured fish production. In contrast, using small size of tank, if failure occurs in one tank, the mitigation on other tanks can be controlled to avoid the loss of entire fish (Timmons \& Ebeling, 2017).

In terms of handling, a large tank requires higher labor cost for maintenance, grading and harvesting fish. In contrast, small size of tank is relatively easier to handle, such as for removing dead fish, tank cleaning, fish feeding and harvesting (Timmons et al., 2002). The visual observation on fish health and growth in a large tank is difficult as there is a high intensity of fish crowding particularly in juvenile (less than $13 \mathrm{~cm}$ of length).

\section{Rotational velocity}

Water velocity in a circular tank is a determinant factor for energy usage of swimming in fish (Timmons et al., 1998; Ross et al., 1995). When fish swims at lower speed than its optimal, a large amount of energy will be used for higher spontaneous activity such as aggression. In contrast, when fish swim at higher speed than optimal, they become stressful, unstable, increase lactate production and fatigue (Davidson \& Summerfelt, 2004; Palstra \& Planas, 2011). Fish distribution in the circular tank is influenced by the heterogeneity of water velocity in the area between inlet flow and the center of the tank (Oca \& Masalo, 2013). Fish distribution in the circular tank is mostly concentrated in the area between high and low velocity area. The high velocity area will be avoided by most fishes as it requires high swimming energy, while dead volumes (low velocity area) are unfavorable condition for fish (low DO and higher metabolites accumulation) (Alamansa et al., 2012; Ross et al., 1995). Thus, the distribution of velocity in the tank is crucial factor in maintaining fish's energy in their optimal range to optimize their growth.

The velocity in the circular tank is influenced by the characteristic of the tank (diameter, water height and roughness) and water inlet feature (impulse force and flow rates) (Oca \& Masalo, 2013). The 
tangential velocity resulted from water inlet has a significant influence in fish behavior and swimming (Andersen et al., 2006; Despres, 2007). The water velocity profiles in different circular tank features

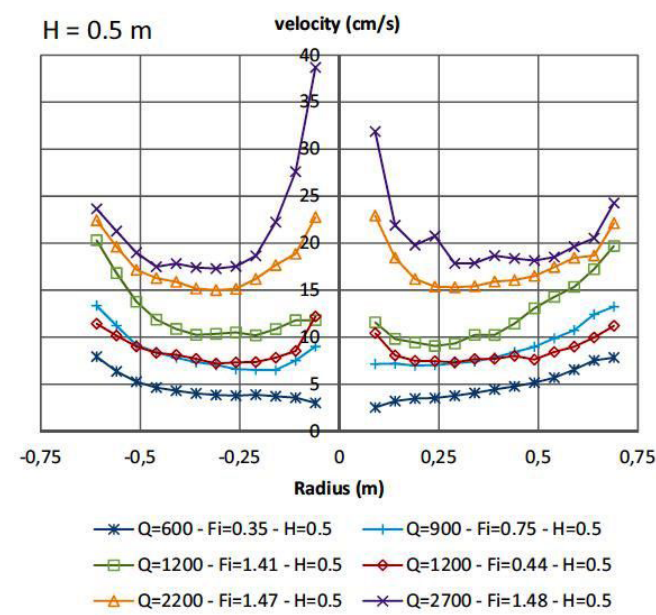

such as water inlet velocity $\left(\mathrm{V}_{\text {in }}\right)$, flow rate $(\mathrm{Q})$, impulse factor $\left(\mathrm{F}_{\mathrm{i}}\right)$ and water depth $(\mathrm{H})$ are presented on illustrations below;

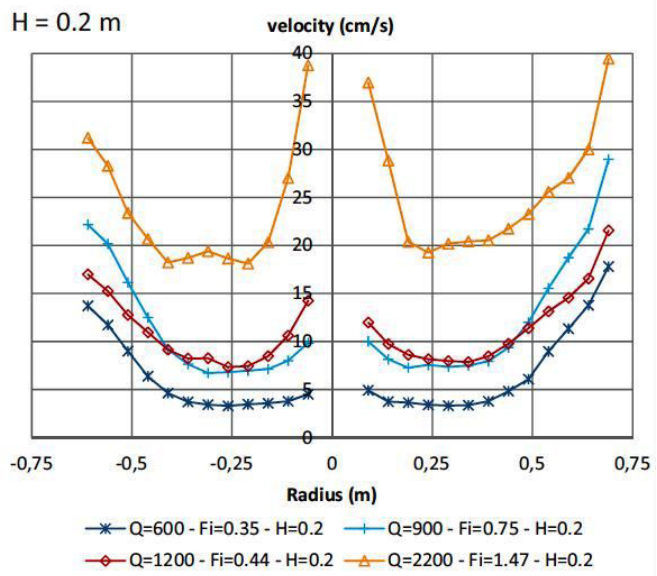

Figure 2. Water velocity profiles in the circular tank with different features of water inlet velocity $\left(\mathrm{V}_{\text {in }}\right)$, flow rate $(\mathrm{Q})$ and impulse factor $\left(\mathrm{F}_{\mathrm{i}}\right)$ using different water depth ( $\mathrm{H}=0.5 \mathrm{~m}$ and $\mathrm{H}=0.2 \mathrm{~m})$ (Oca \& Masalo, 2013).

Figure 2 shows that water velocity in the circular tank decreased from the outer wall (where inlet was installed) to intermediate radius (between inlet and center area) and increased back from the intermediate radius to the center. The continuously increased velocity with radius also occurred on tangential and slope velocity profile. It was concluded that the velocity close to the wall (inlet) increased with impulse factor, while the velocity close to tank center increased with flow rate (Oca \& Masalo, 2013). The effect of water velocity on fish growth is varied in different species, for instance, the survival and growth rate of summer flounder (Paralichthys dentatus) is higher in low velocity, while the growth of Tilapia (Oreochromis niloticus) is higher in high velocity (Belal, 2015; Bengtson et al., 2004). In general, the required water velocity required to maintain the fish' health is from 0.5 to 2 times of fish body length per second (Losordo \& Westers, 1994).

\section{Self-cleaning mechanism}

Self-cleaning ability is an advantage of circular tank which minimizes manual cleaning cost. The self-cleaning mechanism in the circular tank associates with the concentration of settleable solid in the center of tank and solid removal through outlet system (Oca \& Masalo, 2013; Timmons et al., 1998)). To achieve an effective self-cleaning process, primary rotational velocity in central axis of tank should be sufficient 
to generate radial flow along the tank bottom to the center outlet. The velocity of $15-20 \mathrm{~cm} / \mathrm{s}$ is required to drive solid to the center of tank (Timmons et al., 1998). An experiment on feed pellet flushing in 10 and $150 \mathrm{~m}^{3}$ circular tanks indicated that 9.8 to $12 \%$ bottom flow was required to flush feed quickly from the culture tank (Davidson \& Summerfelt, 2004).

The effectiveness of circular tank in self-cleaning process also depends on the fish' movement in relation to resuspending the solid on the bottom of tank. The density of solid from feed and its gravity determine the required settling velocity to concentrate settled solid in the center of the tank. A number of studies in more than 10 fish farm showed that the particle density ranged from 1050 to
$1190 \mathrm{~kg} / \mathrm{m}^{3}$ and particle with different size and shape could be had different densities (Patterson et al., 2003; Chen et al., 1993; Anon, 1995; Tchobanoglous \& Schroeder, 1985). The density of either pellet or feces requires different settling velocities to be effectively concentrated in the center of tank. Feed pellet settling velocity was reported to be faster than feces $(15-33 \mathrm{~cm} / \mathrm{s})$ (Juell, 1991).

Another configuration that is important to achieve optimal solid removal is surface loading rate on the bottom drain (particularly for system applying internal stand pipe). A minimum of 5.4 to $7.9 \mathrm{~L} /$ minute $/ \mathrm{m}^{2}$ is necessary to rapidly remove solid waste in 10 and $150 \mathrm{~m}^{3}$ circular tank volume (Table 1) (Davidson \& Summerfelt, 2004).

Table 1. The relationship of water flow discharge and surface loading rate with removal time of solid from culture tank

\begin{tabular}{cccc}
\hline $\begin{array}{c}\text { Tank volume } \\
\left(\mathrm{m}^{3}\right)\end{array}$ & $\begin{array}{c}\text { Flow discharged of bottom } \\
\text { drain }(\%)\end{array}$ & $\begin{array}{c}\text { Surface loading rate on } \\
\text { bottom drain }\left(\mathrm{L} / \mathrm{min} / \mathrm{m}^{2}\right)\end{array}$ & $\begin{array}{c}\text { Removal time from bottom drain } \\
(\text { minute })\end{array}$ \\
\hline 10 & 12 & 5.4 & $2.0 \pm 0.9$ \\
10 & 6 & 2.7 & Poor solid flush \\
150 & 11 & 7.9 & $1.5 \pm 0.21$ \\
150 & 9.8 & 7.1 & $2.05 \pm 0.42$ \\
150 & 4.3 & 3.1 & Fail to flush solid \\
\hline
\end{tabular}

(Davidson \& Summerfelt, 2004)

Finally, the uniform water velocity and self-cleaning in the circular tank are important features that make circular tanks are more advantageous than other tanks. Water velocity in the circular tank is controllable to achieve self-cleaning mechanism by adjusting inlet and outlet flow. The configuration of inlet and outlet flow structure is the most critical factor in achieving uniform water velocity and self-cleaning process
(Tvinnereim \& Skybakmoen, 1989).

\section{Inlet and Outlet Configuration}

The inlet and outlet configurations in the circular tank determine water velocity, water exchange rate and water mixing allowing all fish reared in the tank to be exposed in the uniform water quality. The design of inlet and outlet structure applied in circular tanks are varied depending on purposes such as 
better mixing, faster settling velocity, species and stage of fish being cultured (juvenile and adult) (Timmons et al., 1998).

\section{Inlet configuration}

In general, inlet flow in the circular tank is injected tangentially at the outer radius of the tank (tank wall) to create water spinning to the center of the tank resulting primary rotating flow. The non-slip condition characteristic between primary flow and tank's bottom and side wall generates secondary flow. The secondary flow includes inward radial flow at the bottom of the tank and outward radial flow at the tank surface
(Timmons \& Ebeling, 2017; Timmons et al., 1998).

The design and configuration of inlet pipe at the outer radius of circular tank influences the tank hydraulic generated from injecting water flow. The different structures of inlet pipe will result in the variety of water flow characteristic such as water velocity, mixing and flushing. The maximum uniformity condition in the tank can be achieved using the combination of both vertical and horizontal branches of inlet pipe (Tvinnereim \& Skybakmoen, 1989). The variation of inlet structures is presented at table 2 and figure 3.

Table 2. Inlet structures and characteristics of water flow in the circular tank

\begin{tabular}{|c|c|}
\hline Type of inlet & Water flow characteristic \\
\hline Traditional open-ended pipe & $\begin{array}{l}\text { Non-uniform velocity profile, poor mixing in the irrotational zone, high } \\
\text { velocity in the tank wall area, re-suspension of solid, poor solid flushing }\end{array}$ \\
\hline Horizontal submerged pipe & $\begin{array}{l}\text { Improve water mixing, weaker/less stable bottom current, poor settling } \\
\text { velocity for solid cleaning }\end{array}$ \\
\hline Vertical submerged pipe & $\begin{array}{l}\text { Better self-cleaning, stronger bottom current, short circuiting, poorer mixing } \\
\text { in the irrotational zone }\end{array}$ \\
\hline $\begin{array}{l}\text { Combination of vertical and horizontal } \\
\text { submerged pipe }\end{array}$ & $\begin{array}{l}\text { Uniform mixing, prevent short circuiting of flow, uniform velocity along depth } \\
\text { and radius, effectively drive waste solid to the center and out of the tank }\end{array}$ \\
\hline
\end{tabular}

(Timmons et al., 2002; Tvinnereim \& Skybakmoen, 1989)

horizontal and vertical influent

injection pipes with orifices

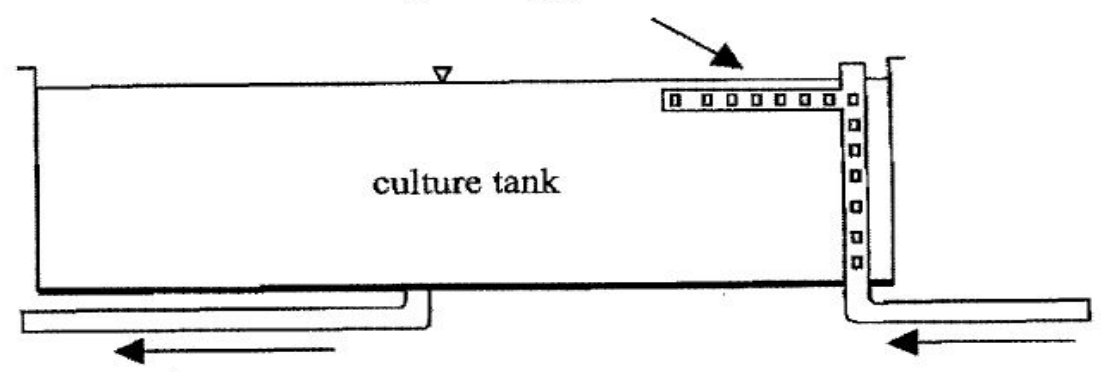

Figure 3. The schematic design of vertical and horizontal inlet configuration in the circular tank (Timmons et al., 2002) 


\section{Outlet configuration}

Outlet configuration in the circular tank is an important feature in concentrating settleable solids such as fecal matters, feed fines and uneaten feeds at the bottom center of the tank. Generally, outlet system of circular tank is installed in the center of the tank (applying single drain system) or adding outlet pipe in the top side of the tank (applying dual drain system).

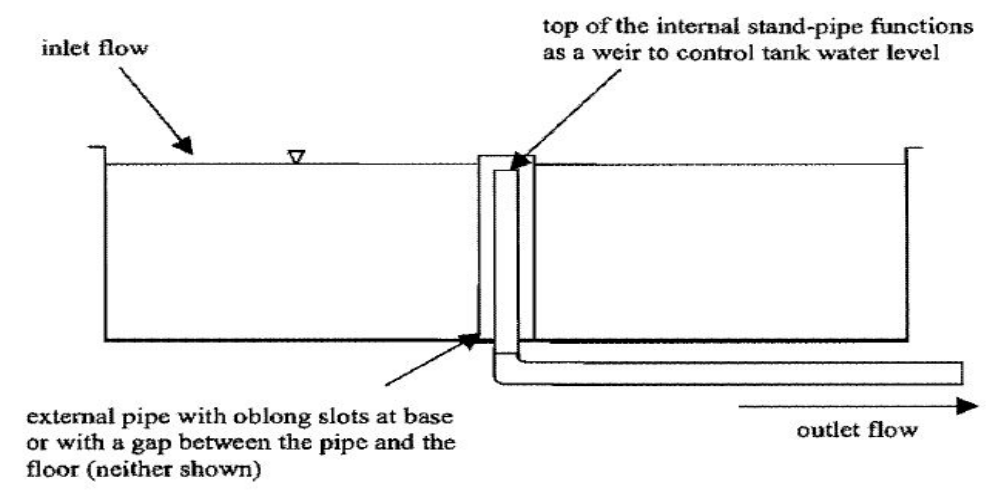

Figure 4. Schematic design of effluent internal stand-pipe in single drain system (Timmons et al., 2002)

The center standpipe allows to captures and store settled solid just close to the drain which eventually withdraws the concentrated solid through the outer pipe oblong with gap between pipe and bottom floor. While the perforated slots at the base of the outer pipe forces water flow generating water suck mechanism, the inner pipe is used to maintain water depth in the tank through over flow mechanism. The distance between two pipes (diameter gap between outer and inner pipe) in internal effluent standpipe should achieve enough velocity to pull the settled solid up (Timmons et al., 2002). The similar mechanism occurs in the circular tank outlet applying external effluent stand-pipe. However, filter should be added at the center bottom of drain to avoid fish escape from the tank (Fig. 5) (Timmons et al., 2002).

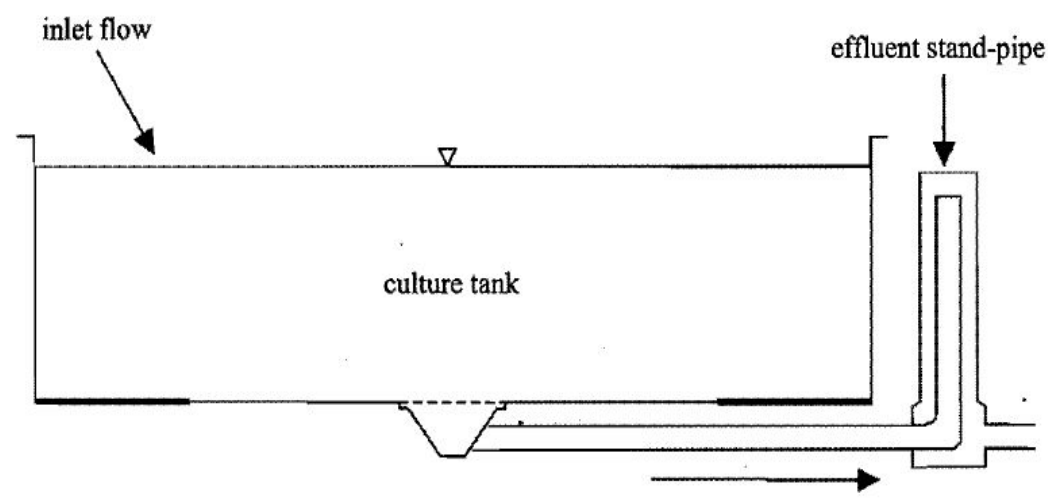

Figure 5. Schematic design of external effluent stand-pipe in single drain system (Timmons et al., 2002) 


\section{Problem of utilizing circular tank}

Despite of its advantageous features, the circular tank has some downsides as compared to other type of tank such as rectangular. In general, problems and challenges faced by circular tank are described as follows;

\section{Floor space utilization}

The dimension of circular tank will cost floor space usage which influences the total production cost of farming. In terms of floor space utilization, a rectangular tank is more effective as it can be arranged parallel from one tank wall to another which is not occurred in the circular tank. To address this problem, relatively large size of circular tanks is used to minimize production cost such as building and maintenance cost. The accumulation cost of flow, fish feeder,
DO probes and float switches could be minimized by applying a large circular tank (Summerfelt et al., 2009).

\section{Handling and harvesting}

The application of circular tank requires more effort in fish handling. The visual fish observation, dead fish removal and fish harvesting in a circular tank, particularly large size tank, are more difficult than in rectangular tanks. Concentrating fish in the corner of rectangular tank during grading or harvesting is not happened in the circular tank. Advance configuration is necessary during fish harvesting and grading in a circular tank. Purse seine should be applied to crowd the fish in the center of circular tank, while 3-panelclam-shellgrader is used to grade fish (Summerfelt et al., 2009).

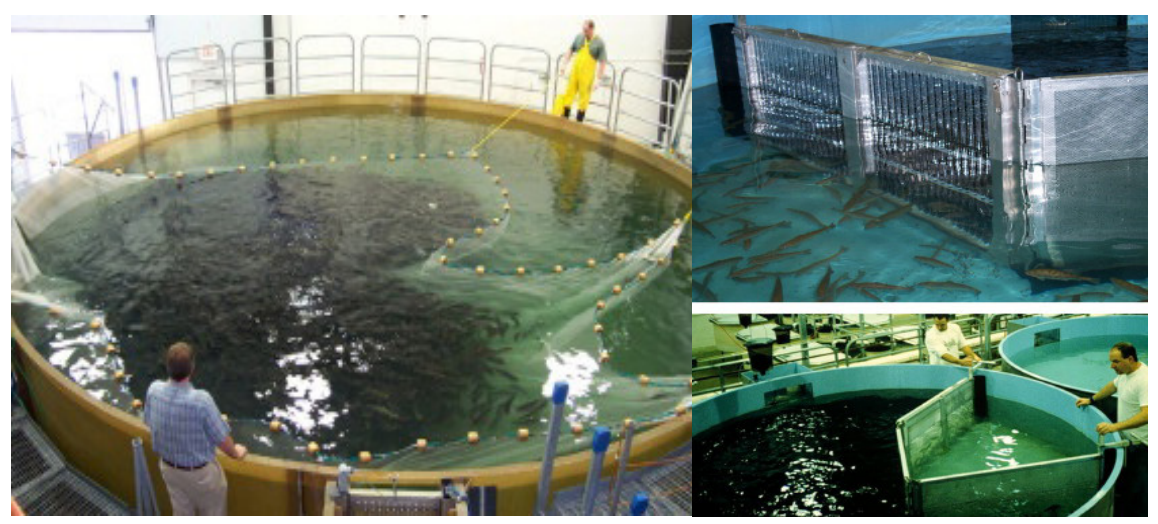

Figure 6. The application of purse seine (left) and 3 panel clam shell in advance harvest technology in a large circular tank (Summerfelt et al., 2009)

\section{References}

Adamu, K. M., R. B. Ikomi and F. O. Nwadukwe. 2014. The Design of Prototype Recirculating Aquaculture
System and its Use to Examine the Histology of Hybrid Catfish Fed Practical Diets. International Journal of Fisheries and Aquatic Studies 1: 242-249. 
Alamansa, C., L. Reig and J. Oca. 2012. Use of laser scanning to evaluate turbot (Scophthalmus maximus) distribution in raceways with different velocities. Aquaculture enginering 51: 7-14.

Andersen, A., T. Bohr, B. Stenum, J. J. Rasmussen and B. J. Lautrup. 2006. The bathtub vortex in a rotating container. Fluid Mechanics 556: 121-146.

Anon. 1995. Water recirculation for salmonids; final study report for $N B$ fisheries and aquaculture contract 291. Babtie International Ltd. Glasgow: 145 pp.

Belal, I. E. 2015. Effect of Water Velocity on Tilapia Oreochromis Niloticus Fingerlings Growth Parameters and Body Composition. Journal of Medical and Bioengineering 4: 457-460

Bengtson, D., S. Willye, E. McCaffrey and D. Alves. 2004. Effects of water velocity on conditioning of summer flounder, Paralichthys dentatus, for net pens. Journal of Applied Aquaculture 14: 133-142.

Chen, S., M. B. Timmons, D. J. Aneshansley and J. J. Jr. Bisogni. 1993. Suspended solids characteristics from recirculating aquaculture systems and design implications. Aquaculture 112: 143-155.

Cripps, S. J. and M. G. Poxton. 1992. A review of the design and performance of tank $\mathrm{s}$ relevant to flatfish culture. Aquacultural engineering 11: 71-91.

Davidson, J. and S. Summerfelt. 2004. Solids flushing, mixing, and water velocity profiles within large $\left(10\right.$ and $\left.150 \mathrm{~m}^{3}\right)$ circular 'Cornell type' dualdrain tanks. Aquacultural Engineering 32: 245-271.

Despres, B. 2007. Hydrodynamic characteristics of multidrain circular tanks. Thesis. University of New Brunswick, Canada: 124 pp.

Duarte, S., L. Reig, I. Masalo, M. Blanco and J. Oca. 2011. Influence of tank geometry and flow pattern in fish distribution. Aquacultural Engineering 44: 48-54.

FAO, 2016. The state of world fisheries and aquaculture 2016. Contributing to food security and nutrition for all. Rome: 200 pp.

Juell, J. 1991. Hydroacoustic detection of waste. A method to estimate maximum food intake of 
fish population in sea cages. Aquaculture engineering 10: 207-217.

Losordo, T. M. and H. Westers. 1994. System carrying capacity and flow estimation. In: Timmons, M. B. and Losordo, T. M. (Eds.), Aquaculture Water Systems: Engineering Design and Management. Elsevier, New York, pp. 9-60.

Morey, R. I. 2009. Design keys of a recent recirculating facility built in Chile operating with fluidized bed biofilters. Aquaculture engineering 41: 85-90.

Palstra, A. P. and J. V. Planas. 2011. Fish under exercise. Fish Physiology and Biochemistry 37: 259-272.

Patterson, R., K. Watts and T. Gill. 2003. Micro-particles in recirculating aquaculture system: determination of particle density by density gradient centrifugation. Aquaculture engineering 27: 105-115.

Ross, R. M. and B. J. Waten. 1998. Importance of rearing-unit design and stocking density to behaviour, growth and metabolism of lake trout (Salvelinus namaycush). Aquacultur engineering 19: 41-46.
Ross, R. M., B. J. Watten, W. F. Krise, M. N. DiLauro and R. W. Soderberg. 1995. Influence of tank design and hydraulic loading on the behaviour, growth and metabolism of rainbow trout (Oncorhynkus mykiss). Aquacultural engineering, 14: 29-47.

Schipp, G., J. Bosmans and J. Humphrey. 2007. Barramundi farming handbook. Department of Primary Industry, Fisheries and Mines, Northern Territory Government. pp. 71.

Stickney, R. R. 1994. Principles of aquaculture. Wiley, New York: $520 \mathrm{pp}$.

Summerfelt, S. T., J. Davidson, G. Wilson and T. Waldrop. 2009. Advances in fish harvest technologies for circular tanks. Aquacultural engineering 40: 62-71.

Tchobanoglous, G. and E. D. Schroeder. 1985. Water quality. In; Patterson, R., K. Watts and T. Gill (Eds) Micro-particles in recirculating aquaculture system: determination of particle density by density gradient centrifugation. Aquaculture engineering 27: 105-115.

Timmons, M. B and J. M. Ebeling. 2017. Culture tank design [online]. https://cals. 
arizona.edu/azaqua/ista/ ISTA7/RecircWorkshop/ Workshop\%20PP\%20\%20 $\& \% 20$ Misc $\% 20$ Papers $\% 20$ Adobe $\% 202006 / 4 \% 20$ Culture\%20 Tank\%20 Design/Culture\%20 Tank\%20Design.pdf. Diakses pada tanggal 1 April 2017.

Timmons, M. B., J. M. Ebeling, F. W. Wheaton, S. T. Summerfelt and B. J. Vinci. 2002. Recirculating Aquaculture System, $2 n$ edition. Cayuga Aqua Ventures Llc, New York: 769 pp.
Timmons, M.B., S. T. Summerfelt and B. J. Vinci. 1998. Review of circular tank technology and management. Aquacultural engineering 18: 51-69.

Tvinnereim, K. and S. Skybakmoen. 1989. Water exchange and self-cleaning in fish rearing tanks, in: De Pauw, J., E. Jaspers, H. Ackefors and N. Wilkens (Eds.) Aquaculture: Biotechnology in progress. European Aquaculture Society, Bredena, Belgium 1: 1001-1047. 